Recibido: 18 Octubre de 2018/Aceptado: 10 Diciembre de 2018

\title{
Mayo del 68. Por la subversión permanente*
}

André y Raphaël Glucksmann. 2018. Mayo del 68.Por la subversión permanente. Bogotá: Grupo editorial Penguin Random House.

Manuel Arias Maldonado

Profesor de Ciencias Política

Universidad de Málaga y autor de Antropoceno.

La política en la era humana (Taurus, 2018).

\section{ANDRÉ Y RAPHAËL GLUCKSMANN}
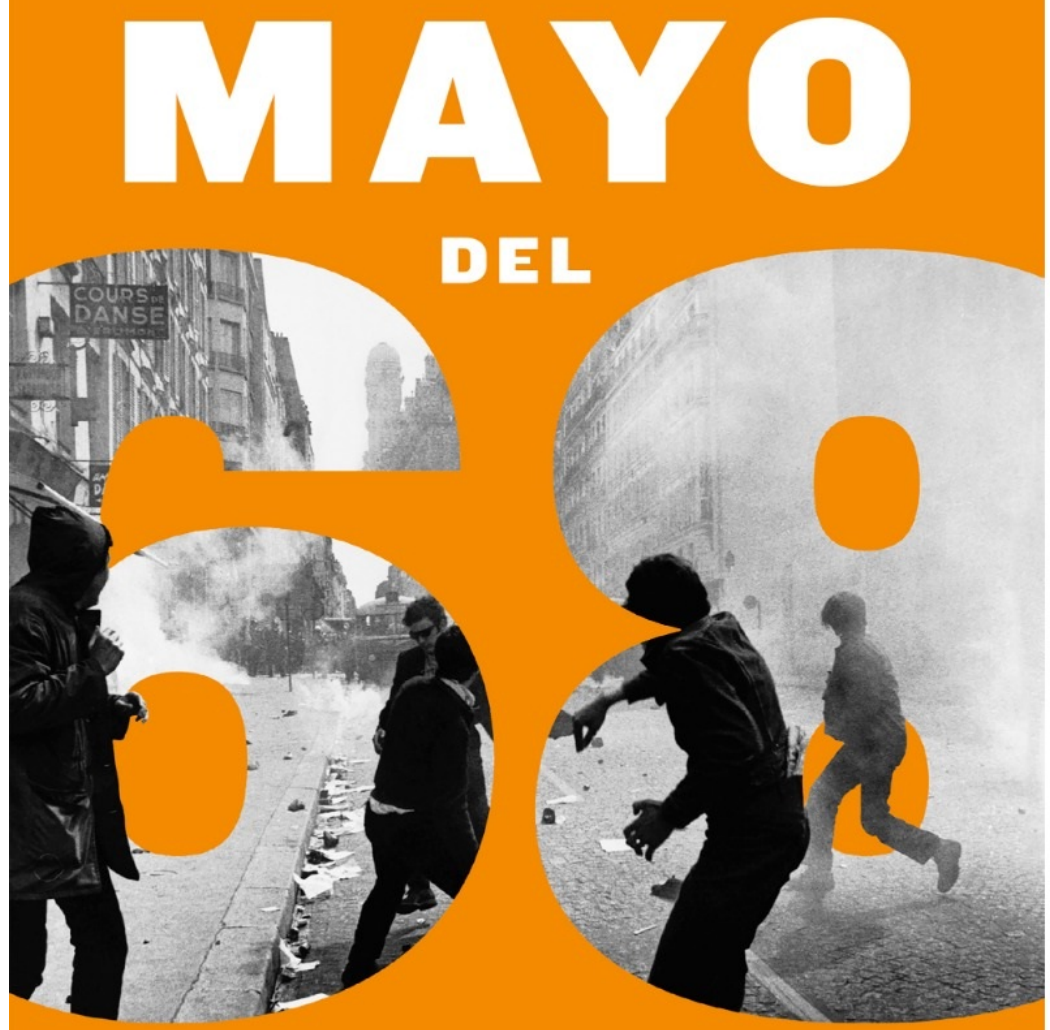

Por la subversión permanente

Nuevo prólogo de Raphaël Glucksmann

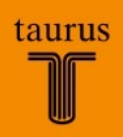

*Publicado en LETRAS LIBRES el 30 septiembre 2008. Tomado de:

https://www.letraslibres.com/mexico-espana/libros/mayo-del-68-por-lasubversion-permanente-andre-y-raphael-glucksmann 
He aquí un libro quintaesencialmente francés. Y dicho sea sin intención peyorativa, aunque acaso tampoco, necesariamente, meliorativa: un libro es francés, se diría, para lo bueno y para lo malo. Francia no sólo es aquel país donde los políticos escriben sino también ese donde los escritores hacen política. Y no es de extrañar que el resultado de todo ello sea una historia política nacional que, al decir de Ciorán, parece hecha por encargo. Así sucede, desde luego, con los breves y ambiguos acontecimientos que sacudieron París en mayo del 68, asombrosamente convertidos en epítome de la contestación global contra el sistema, sin que parezca importar demasiado, a estas alturas, en nombre de qué se levantaban unos y otros, ni contra qué sistema. Así, Praga parece merecer más, pero refulge menos. ¿Acaso por haber gozado de menos favor entre los intelectuales de guardia? Pudiera ser. Sea como fuere, aquí tenemos otro libro sobre el 68 francés; un libro, conviene apresurarse a señalar, distinto a los demás: pero no menos francés.

Resulta por eso llamativo que los editores españoles hayan renunciado a mantener su título original: Mayo del 68 explicado a Nicolás Sarkozy. Difícilmente lo habrán hecho para evitar un localismo desconcertante, ya que la notoriedad del actual presidente francés -ratificada en la industria editorial española por la edición en Anagrama de El alba la tarde o la noche, el notable libro que le ha dedicado Yasmina Rezaparecería garantizar la atención del público. Quizá, habría que matizar, de cierto público, pero no de aquel que busca en la conmemoración del mayo francés la confirmación del argumentario tradicional en torno a aquellas jornadas: ¡los que estuvieron allí! Sin embargo, esta obra conjunta de André Glucksmann, enfant terrible de la filosofía francesa, y de su hijo Raphaël, enfant no tan terrible y filósofo también, constituye una defensa del 68 ante los ataques de Sarkozy, si bien una defensa que desemboca allí donde los sesentaiochistas nunca habrían esperado encontrarse: en el liberalismo.

¿Por qué atacar el Mayo del 68 para ganar las elecciones presidenciales de 2007? Esta es la pregunta que provoca una reflexión orientada a elucidar el significado de aquel acontecimiento, para mejor explicar su fuerza de gravitación sobre el presente. Muchas de las claves políticas y sociológicas manejadas por los autores son nacionales, pero accesibles: desde De Gaulle a Rocard, Francia se postula aquí a la vez como peculiaridad irreductible y como símbolo de Europa. Y los temas en torno a los cuales se articula esta indagación -a través de una conversación a dos bandas y posteriores ensayos individuales- son característicos del sello filosófico familiar. Todos pueden resumirse en uno de los aforismos que jalonan el libro: "Tucídides tenía razón frente a Hegel." Es decir, la razón no es suficiente para dar cuenta de la Historia, cuyo carácter trágico es inmutable; y un exceso de razón puede llevarnos a negar la realidad: así el postestructuralismo, así el posmodernismo, así la izquierda sentimental. Donde Glucksmann senior subraya la lucidez de los sesentaiochistas para lanzar un grito insurreccional frente a la tiranía y renunciar a las pompas del Partido Comunista, Glucksmann junior se pregunta dónde estaba ese inconformismo durante el genocidio de Ruanda, cuando aquellos rebeldes ya habían entregado la izquierda francesa al dudoso François Mitterrand. Gloria y miseria del 68.

Desde este punto de vista, el antiautoritarismo radical de entonces habría desembocado en una huida de lo propiamente político, de consecuencias acaso imprevistas. Y esta negación de la realidad se habría manifestado de distintos modos. Filosóficamente, mediante el conjunto de pensadores, desde Heidegger y la Escuela de Frankfurt hasta Derrida \& Co., que habrían culpado a la razón de los males del siglo, trocando la idea de verdad por la de interpretación. Históricamente, dando lugar a una Europa moralizante pero débil, edificada como una Suiza de altos vuelos incapaz de reconocer la necesidad de actuar: Ruanda, Chechenia, los Balcanes. Y políticamente, mediante la renuncia al Estado en beneficio de la libertad individual, lo que, si bien ha permitido el relativo florecimiento de la sociedad civil posbélica, ha hecho germinar un populismo antiestatalista verdaderamente irrazonable: laborare stanca. Raphaël, ante este panorama, eleva una acusación transgeneracional: 
"Habéis transformado mi vida en una orgía y mi país en un lupanar." Nada menos. Sin embargo, el legado de Mayo es más ambiguo que eso, siempre y cuando el lector acepte el nacimiento de una categoría separada de su objeto: un significado que se emancipa de su significante. Seamos serios: las jornadas parisinas no dan, en sí mismas, para tanto. Pero la discusión intelectual en torno a las mismas y el indudable carácter dramático de aquellos sucesos han terminado por otorgar al Mayo francés un alto valor como condensación simbólica de transformaciones sociales más amplias, a saber: la democratización de la sociedad postindustrial de masas. Para lo bueno y para lo malo. Más que un acto decisivo, el 68 es una escenificación, entre Brecht y Godard, de los nuevos tiempos.

Sucede que esa misma cualidad lo ha convertido en un fetiche. Y de ahí que André Glucksmann distinga entre el 68 histórico -donde, afirma, lo pasaron en grande- y el fantasmal espíritu oficial del 68: la naftalina sobre la chaqueta de pana. No es ahí donde podemos encontrar el elusivo significado de Mayo, aventura inacabada y ambigua a la que distinguen sus críticas antes que sus respuestas. Dice André que eso es suficiente, pero no está claro: la negatividad absoluta, a despecho de la positividad de lo real, produce monstruos. Se produce aquí un curioso desdoblamiento, ya que el autor francés atribuye a Mayo la cualidad de "experiencia filosófica colectiva", que conecta con la rebeldía socrática y el escepticismo montaignesco, pero sin liderazgos à la Sartre: una renovación de la clásica insubordinación de la filosofía frente a la política. Sin embargo, esa revolución ha debido ser estéril, o minoritaria, porque ha dejado una huella clara en la libertad de costumbres contemporánea, pero no en las costumbres mismas, tan escasamente filosóficas. Y habría sido, en todo caso, una revolución traicionada por todos aquellos que la hicieron.

Más interesantes, acaso, sean las consideraciones de Raphaël acerca del modo en que el 68 transformó para siempre a las revoluciones contemporáneas, cuyo testigo -ante la habitual arrogancia y el menosprecio de los europeos viejos- han recogido los países del Este: de la revolución de terciopelo a la revolución naranja. Heredera de La Boétie y de su idea de que la tiranía se basa en una ilusión colectiva, Mayo factura una insurrección imaginativa $y$ humorística: "La invención genial de Mayo, su revolución en la revolución, es la transferencia de la violencia, consustancial a toda insurrección, al dominio simbólico." No hay muertos ni mártires: la revuelta opera contra el Estado, pero también al margen del Estado. Y esto, concluye acertadamente Raphaël, no es sino una epifanía liberal, por más que el liberalismo siempre haya sido -siga siendo- el enemigo de quienes ignoran su naturaleza esencialmente anticonservadora. ¡Anatema! Eppur si muove. Desde este punto de vista, el McGuffin sarkozyano tiene un desenlace previsible: aunque ataque al 68, Sarkozy es un hijo del 68. Y no sólo por sus orígenes mestizos ni su aire tan poco versallesco: sobre todo, porque invoca la ruptura, aunque está por ver si conseguirá imponerla. No sabemos si este libro, a él dirigido, le habrá sido de utilidad. Pero lo será para cualquier lector interesado en saber aquello que no suele decirse del 68, su íntima verdad: que nos hizo más libres que antes para ser idiotas, pero también para dejar de serlo. 